\title{
Factors Influencing the Use of Learning Management System in Saudi Arabian Higher Education: A Theoretical Framework
}

\author{
Mohammed J. Sherbib Asiri \\ Educational Technology \\ Faculty of Educational Studies, University Putra Malaysia, Malaysia \\ E-mail: msherbib8@hotmail.com \\ Rosnaini bt Mahmud \\ Foundations of Education \\ Faculty of Educational Studies, University Putra Malaysia, Malaysia \\ E-mail: ros@educ.upm.edu.my \\ Kamariah Abu Bakar \\ Science and Technical Education \\ Faculty of Educational Studies, University Putra Malaysia, Malaysia \\ E-mail: kamarab@educ.upm.edu.my \\ Ahmad Fauzi bin Mohd Ayub \\ Science and Technical Education Dept. \\ Faculty of Educational Studies, University Putra Malaysia, Malaysia \\ E-mail: afauzi@educ.upm.edu.my
}

Received: January 21, 2012 Accepted: February 13, 2012 Online Published: May 10, 2012

doi:10.5539/hes.v2n2p125 URL: http://dx.doi.org/10.5539/hes.v2n2p125

\begin{abstract}
The purpose of this paper is to present the theoretical framework underlying a research on factors that influence utilization of the Jusur Learning Management System (Jusur LMS) in Saudi Arabian public universities. Development of the theoretical framework was done based on library research approach. Initially, the existing literature relevant to the subject was reviewed to determine the important variables related to factors influencing the use of LMS in higher education. The paper provides insights of the external and internal variables or factors that influence the use of Jusur LMS for teaching and learning purposes. The internal variables consist of the attitude of Saudi Arabian faculty members towards using LMS, their beliefs towards e-learning, and their competence level in using LMS. The external variables consist of barriers faced by the faculty members and demographic factors. This study was limited to the use of Jusur LMS, one of the e-learning management tools used in Saudi Arabian universities, and surveyed faculty members of Saudi Arabian public universities. This theoretical framework can be adapted to suit the requirements of other similar studies related to planning and implementation of various technology programs in higher education.
\end{abstract}

Keywords: Learning Management System (LMS), E-learning, Higher education, Theory of Reasoned Action (TRA), Technology Acceptance Model (TAM).

\section{Introduction}

Information and Communication Technology (ICT) has become a major focus of interest in the educational field. There are many benefits which speak for the integration of ICT in education, such as increasing the quality of learning (Chang, 2008), providing learners with technological skills and encouraging learners to be more interactive 
(van-Braak, 2001), promoting teachers and students' performance and motivation, and removing the limitations of time and space in instructional processes (Al-Zaidiyeen, Mei, \& Fook, 2008; Alzamil, 2006).

The breakthrough of ICT and its wide application in education has led to the introduction of new terms in the pedagogical field, such as e-learning, virtual class, digital contents, knowledge management, and web-based learning. Furthermore, e-learning in the $21^{\text {st }}$ century has greatly altered the role of instructors. Traditionally regarded as mainly oral transmitters of knowledge they have become subject facilitators and mentors (Al-Khalifa, $2010 \mathrm{~b}$; Bates, 2005). Many factors were found to influence the use of technology by instructors, or in this case, faculty members. This study attempts to identify the factors influencing the utilization of the Jusur Learning Management System of faculty members in Saudi Arabian universities.

\section{The Need for E-learning in Saudi Arabia}

E-learning and its facilities are being more and more frequently adopted in Saudi Arabian universities, a phenomenon which is mainly caused by the steady rise of the Saudi Arabian student population in higher institutions. In the academic year 2008/2009, the student population of altogether 20 universities totaled 608,000 students (Ministry of Higher Education, 2008). Saudi Arabian universities are now facing problems because of overcrowding. In response to this increased demand, the use of information technology is generally viewed the most viable solution to meet this challenge. However, the pressing need to adopt computer technology and e-learning in higher education also means that Saudi Arabian faculty members have to integrate information technology into their classrooms and use IT facilities as part of their teaching processes.

Like other universities in developing countries, Saudi Arabian universities suffer from a shortage of faculty members, especially in applied and medical specializations (Mazi \& Obuamh, 2002). One of the greatest benefits of e-learning is that it helps to reduce the dependency on local teaching staff (Alzamil, 2006). Thus, through the use of e-learning the problem of staff shortages can be minimized because the internet allows the design of interactive course-material which is then delivered over the network to the attending students (Clark \& Mayer, 2008).

The education system in Saudi Arabia is - like all domains of Saudi Arabian public life - based on complete separation of students and staff by gender. Hence, educational institutions have to provide separate buildings and staff for their male and female students. This puts a considerable strain on available resources and accommodation. In this respect, Alaugab (2007) confirms that "the number of female instructors is lower than male instructors at all academic levels" (p.95). E-learning and its various applications is viewed as the perfect solution to face this challenge. Saudi Arabian universities are thus encouraged to introduce e-learning tools to provide e-courses for their female students in different faculties since such an arrangement would require only a minimum number of female instructors.

\section{Learning Management System}

Multiple networks have emerged as a fourth generation in the e-learning field. Its three main features are the retrieval of large amounts of information, the ability to interact via computer-mediated communication (CMC), and the processing power of the Java language. These characteristics facilitate the creation of new e-learning technologies called Learning Management Systems (LMSs), such as WebCT, Blackboard, Moodle, and Lotus Notes (Garrison \& Anderson, 2003).

Learning Management Systems (LMSs) are also known as Virtual Learning Environments (VLEs) or Course Management Systems (CMSs) and are one of the solutions useful for both students and instructors in e-learning environments (Altun, Gulbahar, \& Madran, 2008; Chang, 2008; Falvo \& Johnson, 2007). Learning Management System is defined as a web-based technology which assists in the planning, distribution, and evaluation of a specific learning process (Alias \& Zainuddin, 2005). Sallum (2008) describes LMS as a high solution package that allows for the delivery and administration of content and resources to all students and employees. This system contains software application and features which make learning content easily accessible and managed. In addition, it helps instructors to provide their students with learning materials and manages student registration.

In Saudi Arabia, the National Centre for E-learning and Distance Learning (NCEL) designed its own LMS in collaboration with Meteor Group of Companies in Malaysia called Jusur LMS (Al-Khalifa, 2010 a). Jusur LMS has been developed according to universal standards, and has 17 tools namely Courseware Controls tool, Course Description tool, Announcements tool, Learning Content Management System tool, Glossary tool, Forum tool, General Chat tool, File Sharing tool, Assignments tool, Tests and Assessment tool, virtual classroom tool, Lecturer Information tool, User Administration tool, Survey Manager tool, Questions Bank tool, Grad Book tool, and Tracking Forum Participation tool (National Centre for e-learning and Distance Learning, 2010). 
The advantages of Jusur LMS as listed by Al-Khalifa (2010b) consist of Jusur LMS being user friendly, very easy to learn how to operate, containing various instructional and administrative functions, helping the students to complete the task quickly, uploading various types of files into its environment, allowing students who have made a mistake when using the system to recover easily and quickly, supporting error messages which suggest how to fix the problems, enabling users access to information and activities at anytime and anywhere, and allowing users to communicate with other students in the course and the tutor electronically.

On the other hand, Jusur LMS has its disadvantages and weak points as addressed by Al-Khalifa (2010a). Users reported that they experienced failure of the search feature in the forum and had difficulties downloading course materials. The Jusur LMS forum may require some improvements in order to reflect a more organized approach to the respective course objective. Al-Salum (2009) stated that Jusur LMS features only English and Arabic language content, the instructor cannot add or remove students from the system independently from the support centre, the forum does not include a list of the users who are online at the time, there exist only two options to browse the topics in the forum (e.g. next, and last), extensive files cannot be uploaded in the form of compressed folders, and Jusur LMS has not been integrated with other systems used in the same university such as faculty members academic portal or registration portal.

\section{Research Aim and Methodology}

The aim of the particular piece of research discussed in this paper has been to form a theoretical framework that can provide the decision makers governing Saudi Arabian educational institutions with a proper insight and deeper understanding of the factors that influence the use of Jusur LMS. The extensive review of already existing publications relevant to this study enabled the author to determine the important variables related to the factors influencing the use of LMS in higher education and identify those existing theories and models which could be applied most appropriately in order to develop a relevant framework. The theoretical framework for the study was constructed based on two well-known and tested theories, namely the Theory of Reasoned Action (Fishbein \& Ajzen, 1975) and Technology Acceptance Model (Davis, 1986).

\section{Factors Influencing Utilization of Instructional Technology}

Seels and Richey (1994) have identified a number of component variables which affect utilization processes in general, namely the ways in which technology is perceived, the degree of user independence, and obstacles to the use of instructional technology. On the other hand, Zhao, Pugh, Sheldon, and Byers (2002) have observed that the successful utilization of technology for teaching and learning purposes is affected by three main factors, namely innovator, innovation, and context:

Innovator refers to the instructor or faculty member. The factors associated with the faculty member are technological proficiency, pedagogical compatibility, and social awareness. The rate of technology use can be successfully increased if the instructor feels that he or she has the ability to use the technology, his or her pedagogical approach is consistent with current technology, and if he or she is aware of the nature of the work environment.

Innovation refers to the nature of the technology itself. It is highly important to determine whether the technological project can succeed or not. This depends on its distance from the existing school practice, the existing school culture, and the availability of technological resources. A second aspect or dimension is the user's dependence on other people to use the innovation or other necessary additional resources required to do so.

Context refers to the availability of infrastructure with social support inside the learning environment. The context of environment has three identifiable aspects, namely human infrastructure (technical staff, administrative staff, and institutionalized policies), technological infrastructure (resources, facilities, and access), and social support (colleagues and administrators).

However, a learning environment rich with technology is insufficient and inadequate to guarantee successful utilization and implementation of technology in higher education (Albirini, 2006). Undoubtedly, the faculty members' acceptance of technology plays also a key role in optimal utilization of LMS in higher education. Their ready acceptance of such a system would lead to increase in usage and motivate students to use LMS in their classes (Al-Busaidi \& Al-Shihi, 2010). This means in the context of education that although the government and relevant ministries can initiate various technology programs, its successful uptake will greatly depend on the teachers or instructors who deploy the technology in their classrooms (Mahmud, 2006). Thus, the role of faculty members in accepting and using Jusur LMS is undoubtedly paramount. 
Dusick (1998) categorized these factors as socio-cognitive factors which include personal, behaviour and environment variables. Personal and behaviour variables refer to knowledge, competency, attitude, perception, beliefs and commitment, whilst environment variables refer to facilities, equipment and support. On the same note, demographic variables such as gender (Venkatesh \& Morris, 2000), age (Mahmud, 2006), experience in using ICT and training (Mahmud \& Ismail, 2010) were also found to influence the use of technology for teaching and learning.

In the respect to technology utilization in Saudi Arabia, several researches have been conducted to investigate the utilization of technology in academic institutions for instructional purposes. These studies confirmed that the level of technology utilization for instructional purposes in Saudi Arabian educational organizations is still below the sufficient level (Al-Asmari, 2005; Al-Kahtani, 2006; Alnujaidi, 2008). Moreover, instructors in Saudi Arabian educational institutions faced several barriers which inhibited their use of technology, more specifically in the form of organizational, technological, and personal barriers. For example, staff development, policy and administrative support, professional programme were among those identified as organizational barriers (Al-Alwani, 2005; Al-Asmari, 2005), as technological barriers variables like access and availability, search strategy, and access and availability of resources in the Arabic language (Al-Kahtani, 2006; Al-Weshail, 1997), and as personal barriers attitude toward technology, computer and internet experience, and technological skills and know-how (Abahussain, 1998; Al-Asmari, 2005; Al-Weshail, 1997; Alaugab, 2007).

\subsection{Internal Variables}

Internal variables consist of a specific combination of factors which were related to users themselves. These variables could act as hindrances between potential users and Jusur LMS. The factors selected to be further explored in the study were attitude, pedagogical beliefs towards e-learning, and level of competency (Table 1).

\subsubsection{Attitude}

According to Fishbein and Ajzen "attitude can be described as predisposition to respond in a consistently or unfavorable manner with respect to given object” (Fishbein \& Ajzen, 1975, p. 6). Schafer and Tait (1986) refer to attitude as a set of feelings and tendencies that influence a person's decision toward people, ideas, or objects. These feelings and tendencies can be positive or negative and can be formed in relation to objects or people. The attitudes variable consisted of three components which were affection, cognition, and behaviour. The affective component usually represents an individual's emotional response or liking to a person or object, the cognitive component consists of a person's factual knowledge about a person or object, and the behavioural component involves a person’s overt behaviour directed toward a person or object (Zimbardo, Ebbesen, \& Maslach, 1977).

The success of any initiative aimed at implementing technology in an educational program depends strongly upon the attitudes of the faculty members involved (Al-Erieni, 1999; Albirini, 2006; Clay, 1999b; Hamdi, 2002; Zhao, et al., 2002). Faculty members who hold positive attitude toward technology feel comfortable in using it and are more ready to overcome arising obstacles (Albirini, 2006; Hamdi, 2002). According to AI-Khaldi and AI-Jabri (1998), the overall attitude the faculty members reflected toward computer technology directly influenced the extent of computer utilization. Similarly, Yang and Yoo (2004) investigated the relationship between the affective attitudes and the cognitive attitudes of users and the extent of their usage of technology. Hence, if the faculty members have a positive attitude toward Jusur LMS, they are more likely to be motivated to use Jusur LMS.

\subsubsection{Pedagogical Beliefs toward E-learning}

In order to achieve a change in teaching practices which results in a more integrated use of technology, there was a need to examine the opinions of the instructors themselves and their beliefs about innovative teaching approaches such as e-learning (Ertmer, 2005). The use of technology in the learning environment more likely increases when the instructors' pedagogical approach to teaching is consistent with selected technology (Zhao, et al., 2002).

According to Fishbein and Ajzen (1975), beliefs refer to "the information he has about the object" (p.12). The complete set of someone's beliefs in respect to the physical and social world and the self is clustered in a belief system (Rokeach, 1976). Pedagogical beliefs toward e-learning refer to the information and opinions that are held by faculty members in general toward e-learning practice and its goals. However, Chang (2008) divided the pedagogical beliefs toward e-learning into the four components of importance of web technology (e.g. Wikipedia, Online database, LMS), design (e.g. learner-cantered, interactivity, social interaction), constructivist approach (e.g. problem-solving), and personal preferences (e.g. trying different communication tools in teaching).

In a qualitative study, Ottenbreit-Leftwich et al. (2010) investigate the educators' beliefs that underlie their use of technology. The educator's beliefs tend to influence educator's specific technology integration practices. The teachers' own beliefs about e-learning approach and instruction media are indeed a critical indicator for the classroom use of technology (Tondeur, Hermans, Braak, \& Valcke, 2008). The teachers' behavioural beliefs about e-learning 
also positively predict the usefulness and ease in which it is used (Kao \& Tsai, 2009). Hence, if the faculty members' believe that the e-learning approach is important and has helpful tools, they are more likely to use Jusur LMS in their teaching and learning practices.

\subsubsection{Competence Level in Using LMS}

Technology skill and competence also play key roles in the adoption of technology in the field of educational instruction. Osika, Johnson, and Butearu (2009) emphasize that the lack of technological competency is one of the main reasons for faculty members refusing to integrate new technology in their teaching. Technology competence is defined as "being able to handle a wide range of varying computer applications for various purposes" (Van Braak, 2004, p.300). As such, faculty members need to have not only the basic skills to deal with technology effectively but also need to have basic knowledge of virtual environments such as Jusur LMS (Izmirli \& Kurt, 2009).

It is obvious that the competency level of faculty members directly influences the use of technology for teaching and learning purposes (Albirini, 2006; Ball \& Levy, 2008; Birinci \& Kılıçer, 2009). In addition, Curbelo-Ruiz (2003) found that the majority of instructors who considered themselves competent users in using web-based technology frequently employed it in their teaching, more than half (78\%) of the participants were found to be familiar with teaching tools in web-based technology, and the level of educators' competencies or skills significantly predicted faculty participation in web-based instruction. Ball and Levy (2008) state that the intention of an instructor to use technology is significantly influenced by computer self-efficacy. On the other hand, self-efficacy is strongly and positively related to computer competence (Shih, 2006). Hence, if the faculty members have enough skills and knowledge to use all Jusur LMS features or tools, they will subsequently use the Jusur LMS for teaching purposes.

\subsection{External Variables}

External variables may exist outside the immediate environment of the system. Organizational, technological, social barriers, gender, computer experience, and training have been identified as external variables as highlighted in previous studies. Table 1 shows the most frequently cited factors in literature influencing the utilization of technology.

\subsubsection{External Barriers Faced by Faculty Members}

In the study, external barriers referred to the obstacles existing in the external environment around the potential users that impeded or inhibited them from using Jusur LMS in their teaching. These barriers faced by faculty members can be categorized into organizational barriers, technological barriers, and social barriers. Organizational barriers refer to "the organizational arrangement to support technology integration in the classroom" (Zhao, et al., 2002, p. 503). Technological barriers are "limited access to useful, relevant, and appropriate hardware and software" (Rogers, 1999, p. 9). Social barriers are defined as the degree to which peers supported or discouraged the user to use technologies (Zhao, et al., 2002).

Technology and human facilities have a direct impact on the increasing level of faculty attention toward using technology (Al-Alwani, 2005; Curbelo-Ruiz, 2003; Zhao, et al., 2002). In any e-learning environment, the technology facilities play a key role in the faculty members' decision to participate in LMS. Some of these are related to logistics, such as the type of equipment considered necessary to deliver instruction, the equipment required for students, the computer software that is necessary, and ways to get access to the Internet (Al-Saif, 2005). Al-Senaidi, Lin and Poirot (2009) and Betts (1998) observed that administrational and technical support acted as a major obstacle to the faculty members' use of computer technology. Hence, in order for the faculty members to make optimal use of LMS, the existing organizational, technological and social barriers need to be identified and either reduced or completely removed in order to ensure their optimal use of Jusur LMS.

Van Braak (2001) emphasized that technological, organisational, and social constraints significantly hindered the introduction of computer-mediated communication. In short, these results reflected the importance of external barriers which stood between the faculty members and their use of Jusur LMS. Any future attempt to employ Jusur LMS in teaching and learning therefore needs to identify the existing barriers which stand between faculty members and their use of the system. Seeking to reduce these existing barriers appears to be critical for the successful implementation of Jusur LMS in Saudi Arabian universities.

\subsubsection{Demographic Factors}

Demographic factors such as gender, computer experience, and training are found to serve as antecedents that determine the technology use among faculty members (Al-Alwani, 2005; Al-Saif, 2005; Bin-Baker, 1996; Tondeur, et al., 2008). The educational system in Saudi Arabia is organized based in gender segregation. Thus, it is important to compare how differently female and male faculty members use technology at their respective institutions. Past researches have shown that female staff generally perceive IT in the instructional process as less useful and more challenging to use, and that the behavioural intention to use e-learning system is lower than that exhibited by their 
male counterparts (Ong \& Lai, 2006). According to Al-Balawi (2007) 71.4\% of male faculty members at Saudi Arabian universities are willing to participate in Web Based Instruction (WBI) compared to only 28.6\% of female faculty members. Vekiri and Chronaki (2008) confirmed that although both male and female display the same level of competence and positive beliefs toward the benefits of using computers, men somewhat utilized technology more frequently than women. Their research also indicated that female participants regarded the use of technology less important in their daily activities than their male counterparts. Tsai and Tsai (2010) also concluded that male users showed a higher level of confidence in using technology more than female users.

Computer experience has been identified as another factor influencing the extent to which faculty members use in their lectures (AI-Khaldi \& AI-Jabri, 1998; Burton-Jones \& Hubona, 2006; Diane M. Dusick \& Yildirim, 2000; Teo, 2008). Existing research reveals that the degree of computer experience encourages or discourages faculty members' to use technology (Tondeur, et al., 2008; Van Braak, 2001). Faculty members' acceptance of computer technology is also affected by the previous computer experience (Al-Ghonaim, 2005; Albirini, 2006). Therefore, it is justified in considering the degree of computer experience as one of the factors which bear a direct influence on the usage rate of Jusur LMS exhibited by faculty members in Saudi universities.

Training and professional development have also been found to contribute significantly to the success of technology implementation in higher education (Al-Alwani, 2005; Diane M. Dusick \& Yildirim, 2000; Pajo \& Wallace, 2001). It has been highlighted that faculty members who attended in-service training and workshops are more likely use and apply what they have learned than those who have not (Al-Alwani, 2005). Al-Kahtani's study shows that Saudi Arabian female faculty members needed more in-service training to be able to utilize the internet efficiently (Al-Kahtani, 2006). Therefore, it can be concluded that, both male and female faculty members' use of Jusur LMS will increase if they engaged more frequently in professional development and workshops related to e-learning. According to Rogers (1999), lack of training related to using technology in classroom can become a major barrier to the integration of technology in higher education.

\section{Models Related to the Study}

At this point it is certainly recommendable to discuss on the theories that can be used as a guide to establish the theoretical model. There are two common theories that have been widely applied in the analysis of the use of technology, namely the Theory of Reasoned Action (Fishbein \& Ajzen, 1975), and Technology Acceptance Model (TAM) (Davis, 1986).

\subsection{Theory of Reasoned Action}

Figure (1.1) displays the Theory of Reasoned Action (TRA) which was first proposed by Fishbein and Ajzen (1975) to understand human forms of behaviour. It was virtually designed to explain human general behaviour across wide domains (Davis, Bagozzi, \& Warshaw, 1989). TRA was extensively used and frequently adapted to determine human's choices and intended patterns of behaviour in their actual usage of technology (Ramayah, Rouibah, Gopi, \& Rangel, 2009). TRA however, consists of three constructs which are: behavioural intention, attitude, and subjective norm.

The theory hypothesizes that the behavioural intention of performing a particular action is determined by individual and social factors. While the individual factor is represented by the individual attitude towards the behaviour, the social factor is determined by subjective norm (Ajzen \& Madden, 1986; Fishbein \& Ajzen, 1975). In TRA, it is believed that the degree of actual behaviour is mainly based on the user's intention. Hence, the user's behavioural intention is a decision to involve in performing the action or not (Liker \& Sindi, 1997).

Theory of Reasoned Action (TRA) also assumes that an individual's beliefs in regard to objects indirectly relates to behavioural intentions. An individual's beliefs refer to the information or opinion he/she holds about a certain object. Therefore, the whole of individual's beliefs constitutes the informational foundation which determine the individual's intentions and behaviour toward performing a certain task (Fishbein \& Ajzen, 1975).

\subsection{Technology Acceptance Model (TAM)}

Davis (1986) developed the TAM model based on Fishbein's and Ajzen's work. To date, TAM has become one of the most widely used models in the field of ICT (King \& He, 2006). The purpose of this model is to explain the determinants of computer acceptance among users (Figure: 1.2). It explains user behaviour across end-user computing technologies and user population (Davis, et al., 1989).

Based on the assumptions of TAM, the behavioural intention to use technology (BI) is determined by the person's attitude toward using the technology (A) and perceived usefulness (U) (BI=A+U) (Davis, 1986). A person's attitude toward a new technology (A) is viewed as an essential determinant in the users' acceptance of a system where individuals form intention to perform behaviour toward which he/she has a positive attitude (Davis, 1986). More so, 
the (A) in the theory is determined by perceived usefulness and perceived ease of use (U+ EOU =A), and finally, variables like training, user support, level of education, age, and system experience which are considered external variables influence user beliefs in using the system (Jones \& Hubona, 2006).

However, some researchers posited that the actual usage of a technology in TAM can be measured using both frequency of use and volume of use (Jones \& Hubona, 2006; Turner, Kitchenham, Brereton, Charters, \& Budgen, 2010). These two measures are based on the volume and frequency in which the technology is utilized, Frequency of use of the system refers to the number of times in which the user utilized a system over a period (e.g. use Jusur LMS twice per week), whereas volume of use of the system refers to amount of time that the user used a system over the same period (e.g. use Jusur LMS four hours per set) (Jones \& Hubona, 2006).

\section{Towards a Theoretical Framework}

The theoretical framework of the study on factors influencing the use of Jusur LMS is based on the assumptions of TRA and TAM. In addition, this study adopts one TRA variable, namely the individual's beliefs toward e-learning which influences individual's behaviour indirectly (Schafer \& Tait, 1986). Similarly, two TAM variables are adopted, namely attitude and external variables. In the Technology Acceptance Model (TAM), the attitude factor has a direct influence on the intention to use a system (Davis, et al., 1989). TAM also presents external variables as an independent determinant with an indirect relationship to the intention to use a technology system. In this study, the adopted variables are reflected by the independent variables, and the dependent variable reflects the utilization level of Jusur LMS.

According to Pac (2008), only a certain percentage of faculty members utilize technology in teaching, while others do not use it at all. Literatures on the utilization domain of instructional technology (Abdalhaq \& Yasin, 2008; Addawood, 1990; Betts, 1998; Zhao, et al., 2002) have identified a number of internal and external factors that contribute to a faculty member's use of LMS. The following factors are based on several studies that focused on technology implementation among faculty members.

One of these factors is attitude toward technology. It is found that faculty members who have positive attitude toward Jusur LMS feel more satisfied with using this technology in their classrooms. The second factor is competence in using Jusur LMS. It is found that faculty members who are knowledgeable and skilful in using Jusur LMS frequently use it more than those are incompetent. In addition, pedagogical beliefs toward e-learning that faculty members hold are considered as one of the main determinants to incorporate Jusur LMS into the teaching environment. The frequency of Jusur LMS use may relate with positive beliefs toward e-learning in general. For example, instructors who hold positive constructivist beliefs may be more likely to adopt Jusur LMS than those who hold more conservative beliefs.

External barriers faced by faculty members which prevent them from using Jusur LMS are considered as a factor that influences faculty members in their use. The three major barriers identified in this study are organizational, technological, and social barriers. These variables exist in the environment around the user that may encourage, discourage or even prevent him or her from using Jusur LMS.

In this model, individual differences among technology users are duly considered, According to Henry and Basile (1994), demographic factors and user characteristics are also likely to have an impact on technology acceptance. Variables such as gender, computer experience, and training have been identified as external variables. Figure 1.3 shows the model of this study, this model could predict the utilization of Jusur LMS in Saudi Arabian universities.

\section{Practical Implications}

Many researches have shown that knowledge of the factors that influence the use of LMS among faculty members can help promote the successful integration of technology in teaching and learning process. Previous research has identified five main factors that need to be taken into consideration when investigating the use of Jusur LMS in Saudi Arabian universities. They are attitude towards the use of LMS, beliefs towards e-learning, competency, barriers and demographic variables. The theoretical framework was then used to direct the investigation related to the factors influencing the faculty members' use of LMS, in particular Jusur LMS. This theoretical framework can be adapted for other studies related to planning and implementation of Learning Management System in higher education.

\section{Research Limitations}

This study limited its scope to examining the factors influencing the use of Jusur LMS in Saudi Arabian universities. However, Jusur LMS constitutes only one of the e-learning management tools which are employed in Saudi Arabian universities. The study population was limited to the faculty members of Saudi Arabian public universities. In 
consequence, the result of the study may not reflect the general use of information technology in higher education as such, and it may not reflect the use of information technology at private universities.

\section{Conclusion}

The rapid developments in the field of Information and Communication Technology (ICT) and utilization of e-learning tools including learning management system (LMS) have become essentials to educational processes. Many higher educational institutions have adopted LMS to increase the quality of learning, equip learners with technological skills, encourage learners to be more interactive, and removing the limitations of time and space in instructional processes (Al-Zaidiyeen, et al., 2008; Al-Zamil, 2003; Chang, 2008). Jusur Learning Management System provides instructors with six efficient functions. It enables educators to register their students in the course, designs the course and the way of teaching it, delivers the course content to users, communicates with student synchronously and asynchronously, follows up the students' progress in the Jusur environment, and evaluates the students' performance.

However, providing the required technological infrastructure does not guarantee the optimal implementation of LMS by all faculty members of the institution. In consequence, every higher educational institution seeks to increase the utilization level of LMS of its faculty members to ensure the successful integration of technology in teaching and learning processes.

There are several factors that can be taken into consideration when using LMS for teaching and learning purposes. The internal variables consist of attitude toward use of LMS, beliefs toward e-learning, and competence level in using LMS and are factors which relate to the faculty members themselves. Attitude toward use of LMS is divided in to three sub-sections namely affect, cognition, and behaviour. Beliefs toward e-learning can be examined from the viewpoint of the importance of web to instructor, design of content, constructivist approach, personal preferences.

On the other hand, external variables are factors which are related to the environment surrounding the faculty members and their characteristics which encourage or inhibit faculty members from using Jusur LMS. The external variables include two important factors which consist of the barriers faced by faculty members and demographic factors. The barriers variable is classified based on Betts's work (1998), and divided into three sub-domains namely organizational barriers, technological barriers, and social barriers. In addition, three demographic factors are found as critical factors that may influence the utilization of Jusur LMS, namely gender, experience in using computer as well as training and attending workshops. The theoretical framework for investigating the factors influencing the utilization of LMS is drawn from the Theory of Reasoned Action (Fishbein \& Ajzen, 1975) and Technology Acceptance Model (TAM) (Davis, 1986).

\section{References}

Abahussain, S. (1998). Implementation of Interactive Television Technology in Distance Education Higher Learning Programs in Saudi Arabia. Unpublished doctoral dissertation, University of Southern California

Abdalhaq, B., \& Yasin, I. (2008). Factors that Affect the Use of Information Technology in the Process of Education in North Palestinian Schools. Journal of Al-Najah University for Human Science, 22(4), 1063-1097.

Addawood, A. S. (1990). Faculty Perceptions of the Use of Educational Technology in Saudi Arabian Universties. Unpublished doctoral dissertation, The George Washington University.

AI-Khaldi, M. A., \& AI-Jabri, I. M. (1998). The Relationship of Attitudes to Computer Utilization: New Evidence From a Developing Nation. Computers in Human Behavior, 14(1), 23-42. http://dx.doi.org/10.1016/S0747-5632(97)00030-7

Ajzen, I., \& Madden, T. J. (1986). Prediction of Goal-Directed Behavior: Attitudes, Intentions, and Perceived Behavioral Control. Journal of Experimental Social Psychology, 22, 453-474. http://dx.doi.org/10.1016/0022-1031(86)90045-4

Al-Alwani, A. E. (2005). Barriers to Integrating Information Technology in Saudi Arabia Science Education. Unpublished doctoral dissertation, University of Kansas, U.S.A.

Al-Asmari, A. M. (2005). The Use of The Internet Among EFl Teachers at Th colleges of Technology in Saudi Arabia Unpublished doctoral dissertation, The Ohio State University.

Alaugab, A. M. (2007). Benefits, Barriers, and Attitudes of Saudi Faculty and Students Toward Online Learning in Higher Education. Unpublished doctoral dissertation, University of Kansas. 
Al-Balawi, M. S. (2007). Critical Factors Related to the Implementation of Web-Based Instruction by Higher Education Faculty at Three Universities in the Kingdom of Saudi Arabia. Unpublished doctoral dissertation, University of West Florida.

Albirini, A. (2006). Teachers attitudes toward information and communication technologies: the case of Syrian EFL teachers. Computers \& Education, 47, 373-398. http://dx.doi.org/10.1016/j.compedu.2004.10.013

Al-Busaidi, K. A., \& Al-Shihi, H. (2010). Instructors' Acceptance of Learning Management Systems: A Theoretical Framework. Communications of the IBIMA, 2010, 1-10.

Al-Erieni, S. A. (1999). Attitudes of King Saud University Faculty Toward Development and Implication of A Telecommunications-based Distance Education Program as an Alternative to Conventional Teaching. Unpublished doctoral dissertation, George Mason University. http://dx.doi.org/10.5171/2010.862128

Al-Ghonaim, H. S. (2005). Attitudes, Barriers, and Incentives of Saudi College Instructors and Administrators toward Implementation of On-line Instruction. Unpublished doctoral dissertation, University of Kansas.

Alias, N. A., \& Zainuddin, A. M. (2005). Innovation for Better Teaching and Learning: Adopting the Learning Management System. Malaysian Online Journal of Instructional Technology, 2(2), 27-40.

Al-Kahtani, N. K. (2006). The Internet technololgy and its Potential Contribution to Research in Saudi Arabia: Possible Factors Influencing its utilization. unpublished doctoral dissertation, The George Washigton University, USA.

Al-Khalifa, H. S. (2010 a). A First Step in Evaluating the Usability of JUSUR Learning Management System. Paper presented at the The 3rd Annual Forum on e-Learning Excellence in the Middle East 2010: Bringing Global Quality to a Local Context. February 1st - 3rd, Dubai, U.A.E.

Al-Khalifa, H. S. (2010 b). E-learning in Saudi Arabia. In U. Demiray (Ed.), E-learning practices (Vol. 2, pp. 745-772). Eskisehir-Turkey: Anadolu University.

Alnujaidi, S. A. (2008). Factors Influencing English Language Faculty Members' Adoption and Integration of Web-Based Instruction (WBI) in Saudi Arabia. Unpublished doctor dissertation, University of Kansas.

Al-Saif, A. (2005). The Motivating and Inhibiting Factors Affecting the Use of Web-Based Instruction at the University of Qassim in Saudi Arabia. Unpublished doctoral dissertation, Wayne State University, U.S.A.

Al-Salum, O. I. (2009, 9 August). Deficiencies in the Jusur Learning Management System, Information Technology. Al-Riyadh newspaper. [Online] Available: http://www.alriyadh.com/2009/08/09/article450962.html

Al-Senaidi, S., Lin, L., \& Poirot, J. (2009). Barriers to adopting technology for teaching and learning in Oman. Computers \& Education, 53, 575-590. http://dx.doi.org/10.1016/j.compedu.2009.03.015

Altun, A., Gulbahar, Y., \& Madran, O. (2008). Use of a Content Management System For Blended Learning: Perceptions of Pre-Service Teacher. Turkish Online Journal of Distance Education, 9(4), 11.

Al-Weshail, A. S. (1997). Use and Integration of Computer and Computer-Related Technology by Faculty Members at the Intitute of Public Adminstration in Saudi Arabia. Unpublished doctoral dissertation, Mississippi State University

Al-Zaidiyeen, N., Mei, L., \& Fook, F. (2008). In-Service Teachers' Attitudes Towards The Use of Information and Communication Technology in Teaching Practice: The cas of Jordan. Proceeding of Paper presented at the the 2nd International Malaysian Educational Technology Convention, , Kuantan, Pahang Darul Makmur, Malaysia.

Al-Zamil, O. A. (2003). High School Social Studies Teachers' Attitudes and Usage of Instructional Technology in Saudi Arabia. Unpublished doctoral dissertation, University of Arkansas.

Alzamil, Z. A. (2006). Students' Perception Towards the E-Learning at The GOTEVOT and the Arab Open University in Riyadh. Journal of King Saud University: Educational Sciences and Islamic Studies, 18(2), 655-698.

Ball, D. M., \& Levy, Y. (2008). Emerging Educational Technology: Assessing the Factors that Influence Instructors' Acceptance in Information Systems and Other Classrooms. Journal of Information Systems Education, 19(4), 431-443.

Bates, A. W. T. (2005). Technology, E-learning and Distance Education: Routledge, Taylor \& Francis Group. UK.

Betts, K. (1998). An Institutional Overview: Factors Influencing Faculty Participation in Distance Education in Postsecondary Education in the United States: An Institutional Study. [Online] Available: Online Journal of Distance Learning Administration http://www.westga.edu/ distance/betts13.html (March 14, 2009) 
Bin-Baker, M. (1996). The Use of Computer Technology by Saudi Administrators in Hgher Education. Unpublished doctoral dissertation, The George Washington University.

Birinci, G., \& Kılıçer, K. (2009). The pre-service teachers' competency perceptions regarding technology planning. Procedia Social and Behavioral Sciences, 1, 1474-1478. http://dx.doi.org/10.1016/j.sbspro.2009.01.260

Burton-Jones, A., \& Hubona, G. S. (2006). The mediation of external variables in the technology acceptance model. Information \& Management 6(43), 706-717. http://dx.doi.org/10.1016/j.im.2006.03.007

Chang, C. L. (2008). Faculty Perceptions and Utilization of a Learning Management System in Higher Education. Unpublished doctoral dissertation, Ohio University, USA.

Clark, R. C., \& Mayer, R. E. (2008). E-learning and the Science of Instruction: Proven Cuidelines for Consumers and Designers of Multimedia Learning. San Francisco: Pfeiffer An Imprint of Wiley.

Clay, M. (1999b). Faculty attitudes toward distance education at the State University of West Georgia. University of West Georgia. [Online] Available: http://www.westga.edu/ distance/attitudes.html (Febryary 14, 2010)

Curbelo-Ruiz, A. M. (2003). Factors Influencing Faculty Participation in Web Based Distance Education Technologies. HERMES, 3(8), 1-9.

Davis, F. D. (1986). A technology acceptance model empirical testing new end-user information systems: Theory and results. Doctoral dissertation, Massachusetts Institute of Technology.

Davis, F. D., Bagozzi, R. P., \& Warshaw, P. R. (1989). User acceptance of computer technology: A comparison of two theoretical models. Management Science, 35(8), 982-1003. http://dx.doi.org/10.1287/mnsc.35.8.982

Dusick, D. M. (1998). What social cognitive factors influence faculty members' use of computers for teaching? A literature review. Journal of Research on Computing in Education, 31(2), 123-137.

Dusick, D. M., \& Yildirim, S. (2000). Faculty Computer Use and Training: Identifying Distinct Needs for Different Populations. Community College Review, 27(4), 33-47. http://dx.doi.org/10.1177/009155210002700403

Ertmer, P. A. (2005). Teacher pedagogical beliefs: The final frontier in our quest for technology integration? . Educational Technology Research and Development, 53(4), 25-39. http://dx.doi.org/10.1007/BF02504683

Falvo, D., \& Johnson, B. (2007). The Use of Learning Management Systems in the United States. TechTrends, 51(2), 40-45. http://dx.doi.org/10.1007/s11528-007-0025-9

Fishbein, M., \& Ajzen, I. (1975). Belief, Attitude, Intention, and Behavior: An Introduction to Theory and Research: Reading, MA: Addison-Wesley.

Garrison, D. G., \& Anderson, T. (2003). E-Learning in the 21st Century: A Framework for Research and Practice. London, U.K: Routledge Falmer. http://dx.doi.org/10.4324/9780203166093

Hamdi, N. (2002). Educational uses of the Internet in Jordanian universities. Journal of Educational Science 2, 3-34.

Henry, G. T., \& Basile, K. C. (1994). Understanding the decision to participate in formal adult education. Adult Education Quarterly, 44(2), 64-82. http://dx.doi.org/10.1177/074171369404400202

Izmirli, O. S., \& Kurt, A. A. (2009). Basic competencies of instructional technologists. Procedia Social and Behavioral Sciences, 1, 998-1002. http://dx.doi.org/10.1016/j.sbspro.2009.01.178

Jones, A. B., \& Hubona, G. S. (2006). The mediation of external variables in the technology acceptance model. Information \& Management 43(706-717). http://dx.doi.org/10.1016/j.im.2006.03.007

Kao, C.-P., \& Tsai, C. C. (2009). Teachers' attitudes toward web-based professional development, with relation to Internet self-efficacy and beliefs about web-based learning. Computers \& Education, 53, 66-73. http://dx.doi.org/10.1016/j.compedu.2008.12.019

King, W. R., \& He, J. (2006). A meta-analysis of the technology acceptance model. Information \& Management, 43, 740-755. http://dx.doi.org/10.1016/j.im.2006.05.003

Liker, J. K., \& Sindi, A. A. (1997). User Acceptance of Expert Systems: a Teast of The Theory of reasoned Action. Engineering and Technology Management JET-M, 14, 147-173. http://dx.doi.org/10.1016/S0923-4748(97)00008-8

Mahmud, R. (2006). ICT Readiness Among Secondary School Teachers. Doctoral Dissertation, Universiti Kebangsaan Malaysia.

Mahmud, R., \& Ismail, M. A. H. (2010). Impact of Training and Experience in Using ICT on in-Service Teachers' Basic ICT Literacy. Malaysian Journal of Educational Technology, 10(2), 6. 
Mazi, A. H., \& Obuamh, A. R. (2002). The reality of the quantitative growth of the faculty members in Saudi universities and its future in King Saud University: case study. Frrom King Saud University, Faculty of Education. [Online]

Available:

http://colleges.ksu.edu.sa/Arabic20Colleges/CollegeOfEducation/Pages/COE_Conferences_Faculty_Development.a spx (June 2, 2012)

Ministry of Higher Education. (2008). Higher Education Statistics. From Ministry of Higher Education Portal. [Online] Available: http://www.mohe.gov.sa/AR/MINISTRY/DEPUTY-MINISTRY-FOR-PLANNING-AND-INFORMATION-AFFA IRS/HESC/Pages/ehsaat.aspx (November 1, 2010)

National Centre for e-learning and Distance Learning. (2009). JUSUR LMS System. From National Center for e-learning and Distance [Online] Available: http://www.elc.edu.sa/portal/index.php?mod=content\&page=27 (December 5, 2009)

Ong, C.-S., \& Lai, J.-Y. (2006). Gender differences in perceptions and relationships among dominants of e-learning acceptance. Computers in Human Behavior, 22, 816-829. http://dx.doi.org/10.1016/j.chb.2004.03.006

Osika, E. R., Johnson, R. Y., \& Buteau, R. (2009). Factors Influencing Faculty Use of Technology in Online Instruction: A Case Study. From Online Journal of Distance Learning Administration. [Online] Available: http://www.westga.edu/ distance/ojdla/spring121/osika121.html (August 4, 2009)

Ottenbreit-Leftwich, A. T., Glazewski, K. D., Newby, T. J., \& Ertmer, P. A. (2010). Teacher value beliefs associated with using technology: Addressing professional and student needs. Computers \& Education, 55 1321-1335. http://dx.doi.org/10.1016/j.compedu.2010.06.002

Pac, R. (2008). Factors That Influence Technology Use during Instructional Time. Unpublished doctoral dissertation, Walden University.

Pajo, K., \& Wallace, G. (2001). Barriers to the Uptake of Web-Based Technology by University Teachers. Journal of Distance Education, 16(1), 70-84.

Ramayah, T., Rouibah, K., Gopi, M., \& Rangel, G. J. (2009). A decomposed theory of reasoned action to explain intention to use Internet stock trading among Malaysian investors. Computers in Human Behavior, 25, 1222-1230. http://dx.doi.org/10.1016/j.chb.2009.06.007

Rogers, P. (1999). Barriers to Adopting Emerging Technologies in Education. Education Resources Information Center. [Online] Available: http://www.eric.ed.gov/ (December 25, 2009)

Rokeach, M. (1976). Beliefs, attitudes and values. A theory of organization and change. San Francisco CA: Jossey-Bass.

Sallum, S. A. (2008). Learning Management System Implementation:Building Strategic Change. [Online] Available: http://findarticles.com/p/articles/mi_hb5835/is_200801/ai_n32281677/?tag=content;col1 (Jan 1, 2008)

Schafer, R. B., \& Tait, J. L. (1986). A guide for understanding attitudes and attitude change. Retrieved 4/7/2009, from Extension Sociology at Iowa State University, Ames, Iowa, USA. [Online] Available: http://www.soc.iastate.edu/extension/presentations/publications/comm/NCR138.pdf

Seels, B. B., \& Richey, R. C. (1994). Instructional Technology: The Definition and Domains of The Field: Bloomington, IN: Association for Educational Communications and Technology.

Shih, H. P. (2006). Assessing the effects of self-efficacy and competence on individual satisfaction with computer use: an IT student perspective. Computers in Human Behavior, 22, 1012-1026. http://dx.doi.org/10.1016/j.chb.2004.03.025

Teo, T. (2008). Pre-service teachers' attitudes towards computer use: A Singapore survey. Australasian Journal of Educational Technology, 24(4), 414-424.

Tondeur, J., Hermans, R., Braak, J. V., \& Valcke, M. (2008). The impact of primary school teachers' educational beliefs on the classroom use of computers. Computers \& Education, 51, 1499-1509. http://dx.doi.org/10.1016/j.compedu.2008.02.001

Tsai, P.-S., \& Tsai, C. C. (2010). Elementary school students' attitudes and self-efficacy of using PDAs in a ubiquitous learning context. Australasian Journal of Educational Technology, 26(3), 297-308. 
Turner, M., Kitchenham, B., Brereton, P., Charters, S., \& Budgen, D. (2010). Does the technology acceptance model predict actual use? A systematic literature review. Information and Software Technology, 52, $463-479$. http://dx.doi.org/10.1016/j.infsof.2009.11.005

Van-Braak, J. (2001). Factors influencing the use of computer mediated communication by teachers in secondary schools. Computers \& Education, 36(41-57). http://dx.doi.org/10.1016/S0360-1315(00)00051-8

Van-Braak, J. P. (2004). Domains and determinants of university students' self-perceived computer competence. Computers \& Education, 43, 299-312. http://dx.doi.org/10.1016/j.compedu.2003.09.006

Vekiri, I., \& Chronaki, A. (2008). Gender issues in technology use: Perceived social support, computer self-efficacy and value beliefs, and computer use beyond school. Computers \& Education, 51, 1392-1404. http://dx.doi.org/10.1016/j.compedu.2008.01.003

Venkatesh, V., \& Morris, M. G. (2000). Why don't men ever stop to ask for directions? Gender social influence and their role in technology acceptance and usage behaviour. MIS Quarterly, 24(1), 115-139. http://dx.doi.org/10.2307/3250981

Yang, H. d., \& Yoo, Y. (2004). It's all about attitude: revisiting the technology acceptance model. Decision Support Systems, 38, 19- 31. http://dx.doi.org/10.1016/S0167-9236(03)00062-9

Zhao, Y., Pugh, K., Sheldon, S., \& Byers, J. (2002). Conditions for Classroom Technology Innovations. Teachers College Record, 104 (3), 482-515. http://dx.doi.org/10.1111/1467-9620.00170

Zimbardo, P., Ebbesen, E., \& Maslach. (1977). Influencing attitudes and changing behavior: Reading, MA: Addison-Wesley Publishing Company.

Table 1. Most frequently cited factors in literature influencing the use of technology

\begin{tabular}{|c|c|c|}
\hline \multicolumn{2}{|r|}{ Variables } & Authors \\
\hline \multirow{3}{*}{ 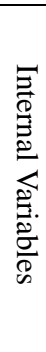 } & Attitude toward use of technology & $\begin{array}{l}\text { Al-Erieni, 1999; Albirini, 2006; AI-Khaldi \& AI-Jabri, 1998; Clay, 1999b; } \\
\text { Fishbein \& Ajzen, 1975; Hamdi, 2002; } \quad \text { Schafer \& Tait, 1986; Yang \& Yoo } \\
\text { 2004; Zhao, et al., 2002; and Zimbardo, Ebbesen, \& Maslach, } 1977 .\end{array}$ \\
\hline & Pedagogical Beliefs toward e-learning & 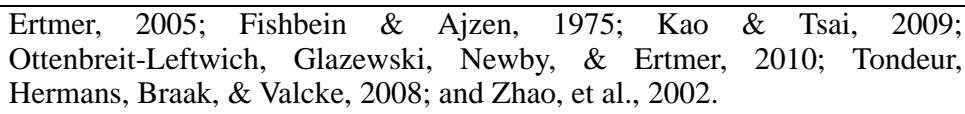 \\
\hline & Competence level in using Technology & $\begin{array}{l}\text { Albirini, 2006; Ball \& Levy, 2008; Birinci \& Kılıçer, 2009; Curbelo-Ruiz, } \\
\text { 2003; Osika, Johnson, \& Butearu, 2009; Izmirli \& Kurt, 2009; and Shih, } \\
\text { 2006. }\end{array}$ \\
\hline \multirow{4}{*}{ 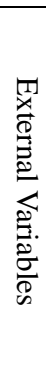 } & External Barriers & $\begin{array}{l}\text { Al-Alwani, 2005; Al-Saif, 2005; Al- Senaidi, Lin and Poirot, 2009; Betts, } \\
\text { 1998; Curbelo-Ruiz, 2003; Van-Braak (2001); and Zhao, et al., } 2002 .\end{array}$ \\
\hline & Computer experience & $\begin{array}{l}\text { Albirini, 2006; Al-Ghonaim, 2005; AI-Khaldi \& AI-Jabri, } \\
\text { Burton-Jones \& Hubona, 2006; Diane M. Dusick \& Yildirim, 2000; } \\
\text { 2008; Tondeur, et al., 2008; and van-Braak, 2001. }\end{array}$ \\
\hline & Gender & $\begin{array}{l}\text { Al-Balawi, 2007; Tsai \& Tsai, 2010; Ong \& Lai, 2006; and Vekiri \& } \\
\text { Chronaki, 2008. }\end{array}$ \\
\hline & Training & $\begin{array}{l}\text { Al-Alwani, 2005; Al-Kahtani, 2006; Diane M. Dusick \& Yildirim, 2000; } \\
\text { Pajo \& Wallace, 2001; and Rogers, } 1999 .\end{array}$ \\
\hline
\end{tabular}

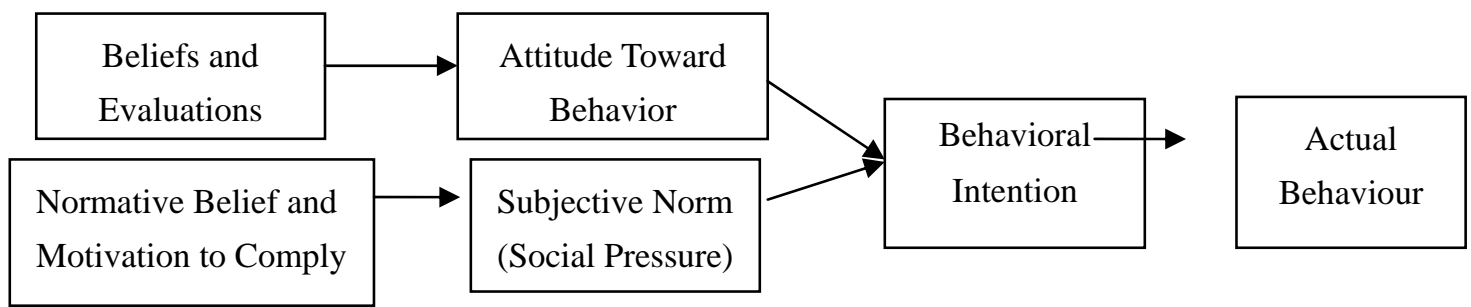

Figure 1.1. Theory of Reasoned Action (TRA), Source: Fishbein \& Ajzen (1975). 


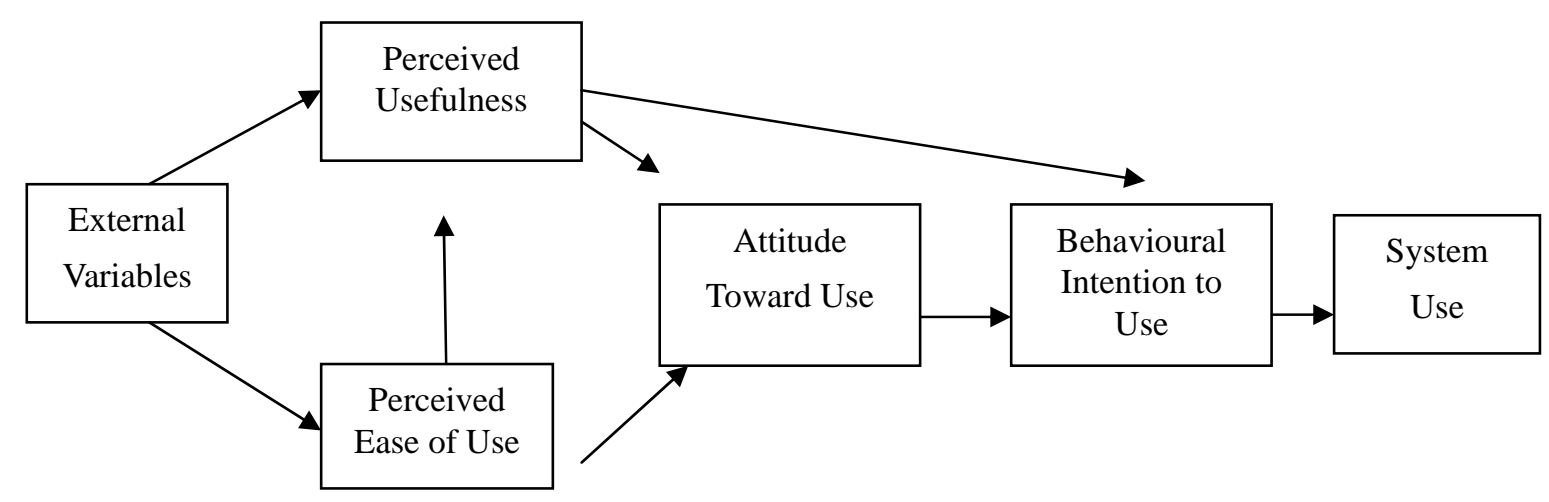

Figure 1.2. Technology Acceptance Model (TAM), Source: Davis, Bagozzi \& Warshaw (1989).

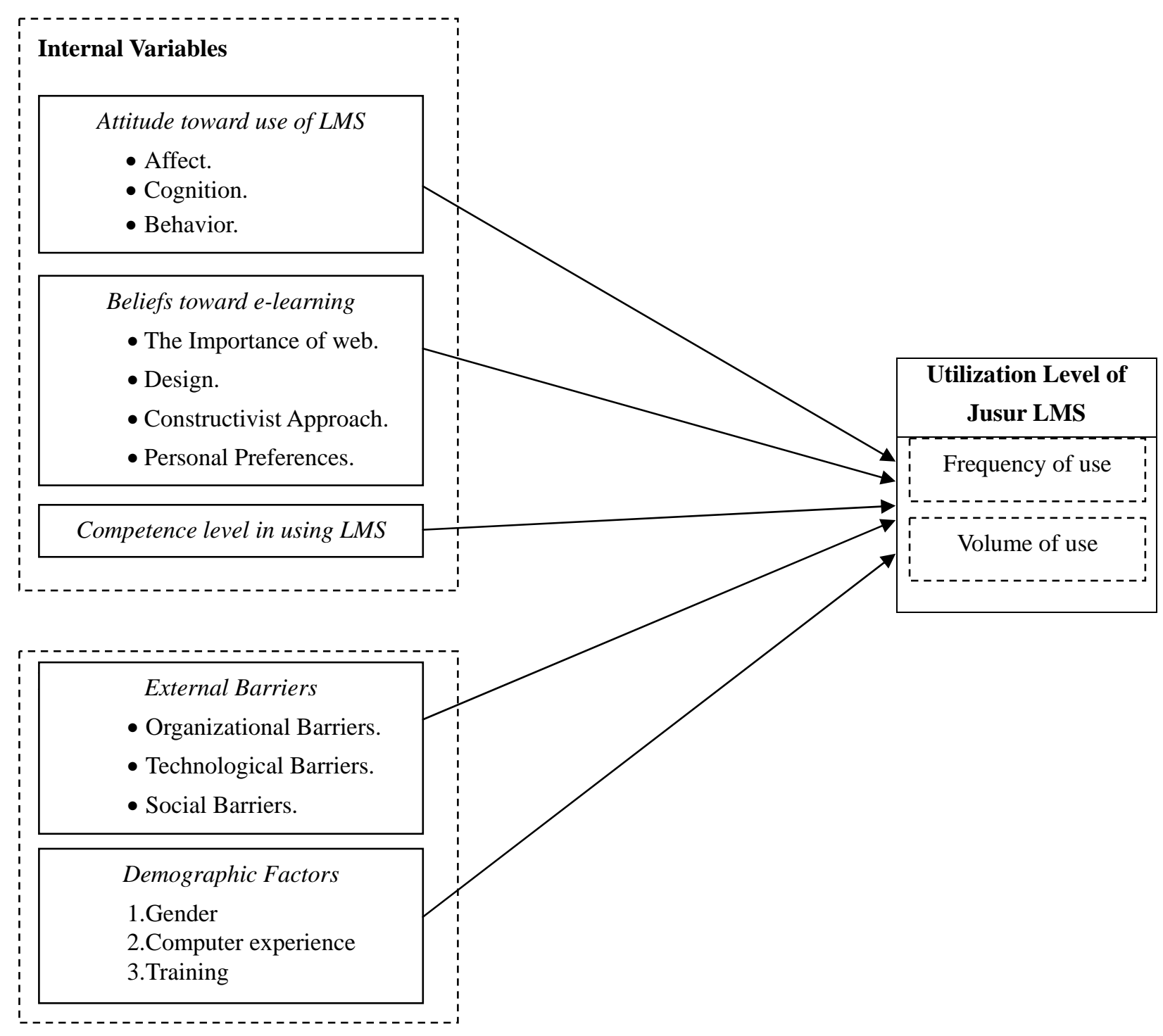

Figure 1.3. Utilization of Jusur LMS framework 